\title{
Subterranean clover in North Canterbury sheep pastures
}

\author{
TOM AND ANNE COSTELLO \\ The Grange, RD Hawarden \\ Carraig@xtra.co.nz
}

\begin{abstract}
Summary
The Hawarden basin is typified by dry, hot conditions over summer, which makes it difficult to retain ryegrass/white clover pastures on the lighter soils. These conditions have led to the introduction of better-adapted species such as the annual, subterranean clover. The mid-flowering cultivar ' $\mathrm{Mt}$ Barker' was first sown in the 1930s; then the earlyflowering 'Woogenellup' and late 'Tallarook' were used in the 1960s. The 'Mt Barker' type became dominant in these old pastures. The key factors for good subterranean clover growth were soil fertility (particularly P and S), space following dry summers for seedlings to re-establish, and moisture in the spring to maximise herbage yield. A visit to Australia in 1996 prompted the inclusion in new sowings of the late-flowering 'Leura' at high sowing rates $(8-10 \mathrm{~kg}$ / ha). It has taken 5 years for seed stocks to build to a level where we can identify good seedling strikes of 'Leura'. Two of the autumns over this period were very difficult and hindered normal establishment.
\end{abstract}

Rainfall is erratic in North Canterbury, which affects the success of subterranean clover from one year to another. Dry summer conditions are optimal for subterranean clover strikes, as the pasture opens, and when the autumn break occurs, more than 2000 subterranean clover seedlings $/ \mathrm{m}^{2}$ can be produced. Autumn grazing management, when recovering from extreme drought, is critical because pasture must be spelled for 6 weeks to allow the subterranean clover to establish. However, if the autumn is wet, pasture cover must be controlled so that subterranean clover seedlings are not smothered. Set-stocking is best in spring to control pasture cover, but grazing should not be too hard during the flowering and seed set period. Subterranean clover seed yields of up to $250 \mathrm{~kg} / \mathrm{ha}$ have been achieved from old pastures, but this is less seed than is produced under Australian conditions. Pasture renovation using the baker boot drill to re-introduce grasses and new cultivars of subterranean clover has been successful following very dry summers.

Lamb growth rates have been excellent on subterranean clover-based pastures and these have increased the farm's meat production and reduced the cost of maintaining pastures.

Key words: grazing management, North Canterbury, seedling establishment, seed set, subterranean clover

\section{Introduction}

We farm 400 ha of flat country in inland North Canterbury at an altitude of $300 \mathrm{~m}$ above sea level. The farm is on relatively light soils, with $60 \%$ of the area as stony silt loam with a moisture holding capacity of about $50 \mathrm{~mm}$, and $20 \%$ of the area consisting of a heavier soil type with moisture capacity of $100 \mathrm{~mm}$. Our farming practice has generally evolved around sustainability on the drier soils. What works on drier soils generally works even better on heavier soils.

The uniqueness of the inland climate means our farm avoids the cooling effect of the easterly winds that are common nearer to the coast. The result of this is that soil temperatures (in the top $0.1 \mathrm{~m}$ ) can reach around $40^{\circ} \mathrm{C}$ in dry conditions during the height of summer. Therefore, sustaining perennial grasses and white clover in our pastures can be difficult in the dry summer and autumn seasons. These climatic conditions have led to the introduction of better adapted annual pasture species such as subterranean clover (Trifolium subterraneum). The season following a wet summer can yield high levels of white clover, but the clover will last for only 1 or 2 years out of 10 . We need clover species that will yield and persist in the other 8 years.

\section{History of subterranean clover on the property}

In the late 1930s subterranean clover was first sown on the property after it was promoted by Professor Hudson, an Australian who at that time was working at Lincoln University. The first cultivar sown was 'Mt Barker', then 'Tallarook' several years later and finally 'Woogenellup' in the 1960s. The idea was to have a range of flowering dates from early ('Woogenellup') to late ('Tallarook') to suit the variability of the seasons in North Canterbury. 
Sowing rate at that time was only $3 \mathrm{~kg} / \mathrm{ha}$, but farmers would ensure a good seeding in the first year by keeping stock off the paddocks at the first flowering. Carrying high pasture cover in late spring created some grass grub problems, but nothing a bit of DDT didn't fix. The increase in pasture production from the first subterranean clover sowings was significant compared with the white clover, which was not surviving the dry summers. With new land acquisitions of heavier soils, through the 1950s and 1960s, subterranean clover was introduced on these blocks too. This resulted in a rapid build up of soil fertility and herbage yield. Until recently there had been no new subterranean clover cultivars introduced and the majority of the subterranean clover growing has been regenerating from those early sowings. By far the most dominant cultivar has been 'Mt Barker', which I would estimate to be $90 \%$ of the clover in our older paddocks.

Inclusion of subterranean clover seed in pasture mixes ceased in the 1980s and started again in the mid1990 s with some newer cultivars. The 1980 s was a period, on our property, of changing from ryegrass to cocksfoot, prairie grass, or tall fescue grass species. The main legume was white clover, which seemed to be a very prostrate and small-leafed type the sheep couldn't graze easily. Lucerne was also used as a legume in a pasture mix but couldn't compete beyond the second year with the grasses. It was at this time that I realized the importance of subterranean clover in our environment. It took these new pastures 3-5 years to once again bulk up with regenerating subterranean clover herbage from hard seed in the ground and give us the early spring yield response we desired.

\section{Key factors for good subterranean clover growth}

1. Soil fertility. This is easily controlled by the input of fertiliser. The property we are on has a long history of superphosphate usage, (averaging 140 $\mathrm{kg} / \mathrm{ha}$ ). Under our non-leaching environment, this maintains Olsen $\mathrm{P}$ levels at around 25-30. Adequate sulphur levels are also important.

2. Space. Subterranean clover doesn't get much of a chance if it is being smothered by a dense population of grass. The hot, dry summer periods, although challenging to farm, do provide the space for subterranean clover to establish and grow when the autumn break occurs.
3. Moisture. Subterranean clover loves moisture, and our best subterranean clover years are when there is a wet winter and spring. We have no control over this factor apart from slowing the evapotranspiration rate by the introduction of shelter.

\section{Visit to Australia}

We visited Australia in the winter of 1996 to investigate if we would benefit from newer cultivars of subterranean clover. We discovered that there was a massive amount of good research being done in the National Subterranean Clover Improvement Programme and that our old cultivars have long since been surpassed. The plant breeding was done in Perth and the cultivars were sent out to other regions for evaluation. We visited research stations in Wagga Wagga (inland NSW), Hamilton (Victoria) and Perth (Western Australia).

A lot of the breeding effort in Australia revolved around resistance to pests and diseases, which at this stage don't appear to be a problem for our New Zealand environment. Diseases such as clover scorch, the red legged earth mite and various viruses are ongoing problems.

The overall consensus was that the new lateflowering 'Leura' and mid-season 'Denmark' should perform well in the temperate New Zealand climate. The advice from the Australians was to direct drill 'Leura' at $10 \mathrm{~kg} / \mathrm{ha}$ into current pastures and leave sheep on to keep the pasture cover down. The ideal subterranean clover type for our environment should grow plenty of feed, grow for the full length of our spring, have the ability to 'kick-on' after a dry spell (i.e. set seed early if necessary but grow again if rain eventuates) and to set high levels of seed, both hard and soft. Our resident type (predominantly 'Mt Barker') fulfils many of these attributes, but we were very interested to determine whether 'Leura' and 'Denmark' are an improvement on the old 'Mt Barker'.

\section{New subterranean clover sowings}

In the autumn of 1997, we direct drilled about 60 ha of 'Leura' at $8 \mathrm{~kg} / \mathrm{ha}$ into resident grass and subterranean clover paddocks. At the time there was concern about how much would survive the competition of the pasture. We continued to graze to keep the cover down and there was some loss of seedlings but we are now identifying good populations of 'Leura'. It appears to have taken five years for subterranean 
clover seed stocks to build to a level where we can identify good strikes of 'Leura' in the original direct drilled paddocks. This is because of a series of difficult years starting with a big false break in the autumn of '98. We found 'Leura' to be a smaller seedling when first establishing, compared with 'Mt Barker'. It has smaller leaves, but much denser herbage, and sets seed in late December, although it will set seed earlier when under moisture stress. The mature plant has reasonably heavy stems which I think helps it to set seed when under moisture stress. 'Denmark' is another cultivar we have sown that appears to give a greater seedling strike after its first seed set. As yet, we haven't tried 'Goulburn', which is the other variety sold by New Zealand seed merchants. I would expect that having the right environment for subterranean clover is more important than the exact variety. With 'Leura' you don't get as much seed per $\mathrm{kg}$ because of the Wrightson coat (30\% of the weight). The relative importance of having a seed coat (or not) on subterranean clover is not known.

The Australian climate is more clear cut than New Zealand's climate between the wet and dry seasons. For example, Perth has an annual rainfall of over $800 \mathrm{~mm}$, but next to no rainfall from November until the autumn break in April or May. This Mediterranean-type climate is ideally suited for annual plants like subterranean clover. The plant is better with no out-of-season rain, which often occurs in New Zealand, because of the subsequent false break and loss to the seed bank. Therefore, in Australia, if a cultivar with the right flowering time is used, a farmer can expect aggressive growth and a high seed yield in most years. In North Canterbury however, our rainfall of $700 \mathrm{~mm}$ is erratic from year to year (variable from 450 to $900 \mathrm{~mm}$ over a 12 -month period), with generally a dry summer going into the autumn. Dry periods can occur at any time, such as in the spring, which can coincide with the optimum seeding time of our subterranean clover. We get adequate seed yields, but not as high as most regions in Australia.

\section{Management for seed set}

We don't do anything special to encourage seed set. We try to carry reasonable pasture cover into the late spring/early summer period to maintain ewes through the following dry months, which would mean we are not grazing subterranean clover plants hard during seed set time. Subterranean clover plants are very good at placing seed. Unlike white clover, which produces its seed up high in a position vulnerable to grazing, subterranean clover sets its seed in burrs on the soil surface with a small percentage finding their way just beneath the soil surface in our soils.

\section{Managing the autumn break}

Our best subterranean clover strikes occur after an extended hot, dry period. The heat seems to soften the seed in preparation. If rain occurs in January, a 'false break' can occur when seed will strike; not high levels, but about 10-20 kg/ha of seed. Many of these seedlings are lost in the following month if conditions go dry again.

The amount of pasture cover plays an important role on the number of subterranean clover seedlings that survive after rain. Too much pasture cover creates competition (as can happen in a high growth year), and many of the seedlings are smothered. A series of good years (moist summers) would result in a reduction of subterranean clover, and white clover would be the appropriate legume to use if you have no problems growing summer pasture.

Conversely, if the pasture is too open, a lot of the seeds on the surface will dry off before they can establish unless conditions remain moist. Thankfully, the mature seeding plant manages to get a certain amount of its seed into cracks in the ground, which can ensure survival under some fairly hostile conditions.

\section{Some example years}

\section{Autumn 98}

In the autumn of 1998, after extreme drought conditions, we had $30 \mathrm{~mm}$ of rain on March $11^{\text {th }}$ and a strike of over 2000 seedlings $/ \mathrm{m}^{2}$. Unfortunately, within 5 days, $90 \%$ of the seedlings were lost. The $10 \%$ survivors were the ones that germinated from below the soil surface. These were in paddocks that sheep were grain feed on and were grazed hard. Although it was disappointing to lose so many seedlings, the numbers left were still greater than we would sow in a new pasture (about $150 \mathrm{seed} / \mathrm{m}^{2}$ ). Subsequent autumn and winter production was reduced, but spring production recovered and was adequate. By contrast, where cattle had grazed, seedling survival was about $70 \%$, due to the fact that there was enough pasture cover to give protection to the seedlings.

\section{Autumn 01}

The autumn of 2001 was also very dry and it was not 
until early May that we had $20 \mathrm{~mm}$ of drizzle over a week. This was our first rain, and the subterranean clover strike was good at 1500 plants $/ \mathrm{m}^{2}$. By the end of May it was very cold and frosty and the seedlings struggled to develop their first clover leaves. Seedling survival through to the spring was quite low because of frost lifting and hoof damage, but spring herbage subterranean clover production was still good.

\section{Autumn 03}

In the first week of April 2003 following a dry late summer, we had $100 \mathrm{~mm}$ of rain followed by cooler weather. Again, 2000 plants $/ \mathrm{m}^{2}$ struck, with the ground cover almost as low as in 1998, and almost every plant survived. Soil temperatures in late March were at $37{ }^{\circ} \mathrm{C}$ in the afternoons and dropped to $18{ }^{\circ} \mathrm{C}$ after the rain. These pastures had no available feed, and were totally browned off with $50 \%$ of the grass dead. They recovered to $1700 \mathrm{~kg} \mathrm{DM} /$ ha of quality feed in six weeks. During this period of favourable conditions, subterranean clover seedlings produced only 3 clover leaves so it is the high seedling population that gives a fast recovery from drought conditions rather than the size of plants.

In summary, if the available cover is above $700 \mathrm{~kg} \mathrm{DM} /$ ha of dry feed at the time of an autumn break, we wouldn't do anything special to protect the seedlings. This cover is adequate and the sheep won't be grazing them to a damaging level. At the point where we have been grain feeding after an extended dry period and the pasture cover was very low, we would remove the sheep and continue feeding supplements on an area of heavier soils for several more weeks. Continuing to feed on short pasture for another 10 days reduces the subterranean clover seedling density by $70 \%$. After drought periods, we can have subterranean clover seedling strikes, on our farm, of $2500 \mathrm{plants} / \mathrm{m}^{2}$, which equates to $180 \mathrm{~kg} /$ ha of seed. I would estimate that our seed banks in older pastures are in the vicinity of up to $250 \mathrm{~kg} / \mathrm{ha}$. Seed banks in Australia can be more than a tonne/ha.

\section{Pasture renovation}

An opportunity arises near the end of an extreme drought period to rejuvenate pastures by using a rugged 'baker-boot' type direct drill to reintroduce grasses and maybe a new cultivar of subterranean clover before any rain. The effect is that the disturbance will bury exposed subterranean clover seed beneath the soil surface and greatly improve the germination and seedling survival. Drilling after the rain is a bit easier on the drill but will damage the resident subterranean clover seedlings that have already struck.

We manage our ewes in large mobs on daily shifts over the winter period behind electric fences, and with the late autumn strikes, we can get substantial subterranean clover seedling loss if we graze within six weeks of germination. However, there is still enough plant survival for good spring production.

The majority of our sowing is after cultivation in the autumn. On our lighter soils, we sow $8 \mathrm{~kg}$ ryegrass, $3 \mathrm{~kg}$ 'Leura', $3 \mathrm{~kg}$ 'Denmark', 2 kg white clover, $1 \mathrm{~kg}$ Cocksfoot, and $1 \mathrm{~kg}$ Caucasian clover.

Clover production is good from the start but it is still taking several years to get the big strikes of subterranean seedlings. I suspect that in our environment the seed remains hard for longer than it does in Australia, which is good when the cultivars we are using are regarded as soft-seeded.

\section{Animal production}

The Hawarden basin is renowned for good early lambs with fast growth rates due to the dry, healthy conditions. Our sheep are run on light country and in wet springs the subterranean clover does very well and lamb growth rates would be up with the best in the area.

In dry springs, we lose our advantage over the farms on heavier country and our lambs do well, but not necessarily better than the heavier country, due to our struggle to maintain pasture cover. To quote lamb growth rates in grams per day would be misleading due to the influence of crossbreeding and rainfall, but without a doubt our meat production would be greatly reduced and our cost to maintain pasture would be greatly increased if it weren't for subterranean clover.

\section{ACKNOWLEDGEMENTS}

Dave Costello for early innovation when farming light soils in North Canterbury. Brian Dear (NSW Agriculture), Dr Ping Si (WA Agriculture), Kevin Reed and Pedro Evans (Agriculture Victoria) for assistance in transfer of knowledge on subterranean clover.

Keith Widdup for assistance in writing. 